\title{
Predicting synchrony and asynchrony in basket cell networks coupled by multiple dendritic gap junctions Tariq Zahid ${ }^{1}$ and Frances K Skinner*1,2
}

\author{
Address: ${ }^{1}$ Toronto Western Research Institute, University Health Network, Toronto, Ontario, M5T 2S8 Canada and ${ }^{2}$ Departments of Medicine \\ (Neurology), Physiology and IBBME, University of Toronto, Toronto, Ontario, Canada \\ Email: Frances K Skinner* - fskinner@uhnres.utoronto.ca \\ * Corresponding author
}

from Seventeenth Annual Computational Neuroscience Meeting: CNS*2008

Portland, OR, USA. 19-24 July 2008

Published: I I July 2008

BMC Neuroscience 2008, 9(SuppI I):PI46 doi:I0.1 I86/I47|-2202-9-SI-PI46

This abstract is available from: http://www.biomedcentral.com/I47I-2202/9/SI/PI46

(c) 2008 Zahid and Skinner; licensee BioMed Central Ltd.

Hippocampal inhibitory interneurons are not a homogenous group of cells, contributing to brain activities in particular and distinct ways. For example, axo-axonic and parvalbumin-positive $(\mathrm{PV}+$ ) basket cells fire preferentially on the peak and descending phases of hippocampal theta oscillations [1].

Basket cells in hippocampus form mutually inhibitory networks and target perisomatic regions of the output pyramidal cell population. Furthermore, they are major players in producing gamma rhythms both in vitro and in vivo [e.g., [2,3]]. Network models incorporating experimentally derived synaptic characteristics produce robust and coherent gamma oscillations, thus suggesting that synchronous output from basket cell networks are important contributors to gamma rhythms. In addition to inhibitory synapses, PV+ basket cells are electrically coupled with gap junctions at multiple locations between their apical and basal dendrites, several hundred microns from their somata [4]. Given that direct electrical communication between neurons plays an important role in shaping network output, it is important to understand how non-proximally located gap junctions contribute to produce synchronous output in basket cell networks. In a previous study we built compartmental models of basket cells with active dendrites and showed that when gap junctions are located distally, there could be sensitive tuning of network dynamics with changes in gap junction conductances [5].
In the work here we built compartmental models of basket cells with different distributions of ion channels in basal and apical dendrites, and explored the dynamics of two-cell networks coupled at non-proximal locations. We first compared full (372 compartments) and reduced (3 compartments) compartmental models to define synchronous and asynchronous regimes. We then quantified phase response curve characteristics in terms of their skewness to predict the network dynamics (synchronous or asynchronous) of reduced models using weakly coupled oscillatory theory. We found that the predictions from quantified phase response curves also held reasonably well when the full compartmental models were coupled at basal or apical dendrites. We next built two-cell networks that were coupled at two and three locations, and computed the average of each of the phase response curves obtained for the different coupling sites. We found that the quantification applied to the averaged phase response curves correctly predicted the network output. This suggests that quantification of phase response curves can be used to predict the output of networks that are coupled with gap junctions at more than one location.

\section{Acknowledgements}

We thank NSERC for funding, and F. Saraga for help with the compartmental models.

\section{References}

I. Klausberger T, Magill PJ, Marton LF, Roberts JD, Cobden PM, Buzsáki G, Somogyi P: Brain-state- and cell-type-specific firing of hippocampal interneurons in vivo. Nature 2003, 42 I:844-848.

2. Hajos N, Palhalmi J, Mann EO, Nemeth B, Paulsen O, Freund TF: Spike timing of distinct types of GABAergic interneuron 
during hippocampal gamma oscillations in vitro. J Neurosci 2004, 24:9|27-9137.

3. Tukker JJ, Fuentealba P, Hartwich K, Somogyi P, Klausberger T: Cell type-specific tuning of hippocampal interneuron firing during gamma oscillations in vivo. J Neurosci 2007, 27:8184-8189.

4. Fukuda T, Kosaka T: Gap junctions linking the dendritic network of GABAergic interneurons in the hippocampus. J Neurosci 2000, 20:1519-1528.

5. Saraga F, Ng L, Skinner FK: Distal gap junctions and active dendrites can tune network dynamics. J Neurophysiol 95:1669-1682.

Publish with Bio Med Central and every scientist can read your work free of charge

"BioMed Central will be the most significant development for disseminating the results of biomedical research in our lifetime."

Sir Paul Nurse, Cancer Research UK

Your research papers will be:

- available free of charge to the entire biomedical community

- peer reviewed and published immediately upon acceptance

- cited in PubMed and archived on PubMed Central

- yours - you keep the copyright

Submit your manuscript here:

http://www.biomedcentral.com/info/publishing_adv.asp 